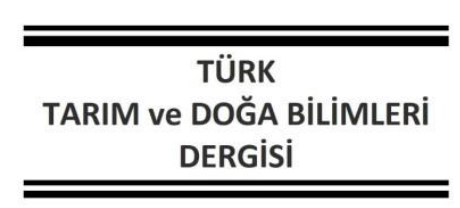

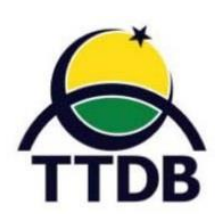

www.dergipark.gov.tr/turkjans

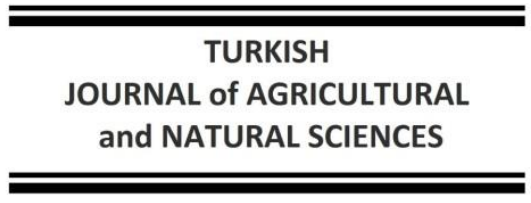

Araştırma Makalesi

\title{
Bazı Kimyasal Uygulamaların Siyah Mürver (Sambucus nigra L.) Tohumlarında Dormansinin Kırılması ve Çimlenme Üzerine Etkisi ${ }^{*}$
}

\author{
Sedanur ODABAŞ ${ }^{1}$, Mehmet Muharrem ÖZCAN², Şevket Metin KARA ${ }^{2 *}$ \\ ${ }^{1}$ Ordu Üniversitesi Fen Bilimleri Enstitüsü Tarla Bitkileri Anabilim Dalı, Ordu \\ ${ }^{2}$ Ordu Üniversitesi Ziraat Fakültesi Tarla Bitkileri Bölümü, Ordu \\ *Sorumlu Yazar: smkara58@hotmail.com
}

\section{Geliş Tarihi: 08.06.2020 Düzeltme Geliş Tarihi: 05.10.2020 Kabul Tarihi: 12.10.2020}

\section{Öz}

Çoğu bitki türünde tohumda dormansinin kırılması ve çimlenmenin teşvik edilmesi amacıyla çok çeşitli fiziksel ve kimyasal uygulamalara yaygın olarak başvurulmaktadır. Bu çalışma konsantre nitrik asit (\%68), konsantre sülfürik asit (\%98) ve gibberellik asidin siyah mürver (Sambucus nigra L.) tohumlarında dormansinin kırılması ve çimlenmenin teşvik edilmesi üzerine etkisini belirlemek amacıyla yürütülmüştür. Doğadan toplanan siyah mürver tohumları farkı sürelerde $(0,15,30,60$ ve 90 dakika) sülfürik ve nitrik asitte bekletildikten sonra farklı dozlarda (0, 500, 1000 ve 2000 ppm) gibberellik asit çözeltisinde 24 saat tutulmuşlardır. Siyah mürver tohumları iklim odasında çimlendirme denemesine alınmış ve çimlenme oranı, kökçük ve sürgün uzunluk ve ağırlıkları belirlenmiştir. Siyah mürver tohumlarının 15 dakikadan daha uzun süre derişik sülfürik asitte bekletilmesiyle çimlenme oranı ve fide gelişimi çok büyük ölçüde gerilemiştir. Siyah mürver tohumlarının konsantre nitrik asitle muamele edilmesi kontrol tohumlarına göre çimlenmeyi ve fide gelişimini şiddetli derecede azaltmıştır. Gibberellik asit uygulaması nitrik asitle ön muameleye tabii tutulmuş siyah mürver tohumlarında hiçbir olumlu etki yapmamıştır. Ancak, 15 dakika sülfürik asitte tutulan siyah mürver tohumları 500 ppm gibberellik asit çözeltisinde 24 saat bekletilince \%100 çimlenme oranına ulaşılmış ve fide gelişimi artmıştır. Bu bulgular siyah mürver tohumlarında fiziksel ve fizyolojik dormansinin birlikte etkili (birleşik dormansi) olduğunu ifade etmektedir. Bu çalışmanın sonuçlarına göre, siyah mürverde dormansinin kırılması ve çimlenmenin teşvik edilmesi açısından tohumların önce 15 dakika derişik sülfürik asitte tutulması ve daha sonra 24 saat süreyle 500 ppm gibberellik asit çözeltisinde bekletilmesi önerilebilir.

Anahtar kelimeler: Asit skarifikasyonu, Fiziksel dormansi, Fizyolojik dormansi, $\mathrm{GA}_{3}, \mathrm{H}_{2} \mathrm{SO}_{4}$

\section{Effect of Some Chemical Treatments on Dormancy Breaking and Germination of Black Elderberry (Sambucus nigra L.) Seeds}

\begin{abstract}
A wide variety of physical and chemical treatments is commonly used for breaking seed dormancy and promoting germination in most plant species. This study was carried out to determine the effect of concentrated nitric acid (68\%), concentrated sulfuric acid (98\%) and gibberellic acid on breaking dormancy and promoting germination in black elderberry (Sambucus nigra L.) seeds. Black elderberry seeds collected form the nature were first soaked in sulfuric and nitric acid solutions for variable durations (0, 15, 30, 60 and 90 min) and then put in different doses $(0,500,1000$ and 2000 ppm) of gibberellic acid solution for 24 hours. Black elderberry seeds were undergone germination tests in climate chamber and percentage of germination, radicle and plumula length and weight were determined. Soaking black elderberry seeds in concentrated sulfuric acid for longer than 15 min significantly decreased germination percentage and seedling growth. Treating black elderberry seeds with nitric acid solution markedly inhibited germination and seedling growth compared to control seeds. The treatments of gibberellic acid did not produce any positive effects on black elderberry seeds pre-treated with nitric acid. However, treating black elderberry seeds that were previously immersed in sulfuric acid for 15 min with 500 ppm gibberellic acid for $24 \mathrm{~h}$ resulted in $100 \%$ of germination and an increase in
\end{abstract}


seedling growth. These results indicate that both physical and physiological dormancy (combined dormancy) are effective in black elderberry seeds. In conclusion, in regarding breaking dormancy and promoting germination and seedling growth, it is recommended that black elderberry seeds can be immersed in concentrated sulfuric acid for 15 min and then soaked in 500 ppm gibberellic acid solution for 24 hours.

Key words: Acidic scarification, Physical dormancy, Physiological dormancy, $\mathrm{GA}_{3}, \mathrm{H}_{2} \mathrm{SO}_{4}$

\section{Giriş}

Mürvergiller (Adoxaceae) familyasında ye alan ve Anadolu'da "yivdin" adıyla da anılan siyah mürver (Sambucus nigra L.) Türkiye'de özellikle Kuzey Anadolu'da çalııı ve fundalık alanlarda doğal olarak bulunmaktadır (Olgun ve ark, 2012; Özdemir ve ark., 2019). Siyah mürverin tüm dünyada asırlardır tıbbi olarak yaygın bir şekilde kullanıldığı ve bitkinin nerdeyse tüm organlarının (kök, yaprak, çiçek, meyve) tıbbi değeri olduğu bilinmektedir. İçerdiği yüksek düzeydeki polifenoller, flavanoidler ve antosiyaninler nedeniyle son yıllardaki çoğu araştırmalarda meyvelerinin antioksidan ve antikanserojen kaynağı olduğu ifade edilmiştir (Atkinson ve Atkinson, 2002; Miraj, 2016). Bitkinin bütün kısımları bronşit, nezle, öksürük, grip, üst solunum, deri ve viral enfeksiyonların tedavisinde ve ağrı kesici, idrar söktürücü ve iltihap giderici olarak kullanılmaktadır (Zakay ve ark., 2004; Odabaş, 2020).

Tıbbı ve aromatik bitkilerin kullanım alanlarının ve tüketimlerinin artmasıyla birlikte bu bitkilerin aşırı ve bilinçsiz bir şekilde doğadan toplanmasına yol açmaktadır (Faydaoğlu ve Sürücüoğlu, 2011). Bazı türlerde doğadan toplamak kısa süreli ekonomik olsa bile, doğadan toplanan bitkilerde yeter miktarda ve kalite standartlarında ürün elde etmek zordur. Bu bakımdan, bilinçsiz ve aşırı toplamayı kontrol alarak doğal florayı korumak ve diğer taraftan da artan talebi karşılamak için tıbbi ve aromatik bitkilerin kültür şartlarında üretimi üzerinde durulmalıdır (Baydar, 2019). Bu bağlamda, özellikle ekonomik önemi yüksek ve birçoğu endemik olan bitki türlerinin uygun tekniklerle çoğaltılması oldukça büyük önem taşımaktadır (Göktaş ve Gıdık, 2019). Tıbbi ve aromatik bitkilerin üretimi ve çoğaltılması generatif ve vejetatif olmak üzere iki yolla yapılmaktadır. Tohumla üretimde, çoğu bitki türlerinde tohumda dormansi ortaya çıktığı için çimlenme ve gelişme yavaş olmakta, çeşitli morfolojik ve kimyasal özellikte oldukça büyük varyasyonlar ortaya çıkabilmektedir (Baydar, 2019).

Canlı tohumun uygun çimlenme koşullarında çimlenememesi olarak ifade edilen dormansi, tohumun gelişimi ve olgunlaşması sırasında ortaya çıkan ve geçici olarak çimlenmeyi durduran bir durum olarak tanımlanmaktadır
(Baskin ve Baskin, 2004; Boyraz ve ark., 2019). Tohumlarda dormansinin kırılması için soğukta katlama, fiziksel aşındırma, asit ve hormonlarda bekletme ve bunların kombinasyonları uygulanmaktadır (Karakurt ve ark., 2010; Hayta ve Arabacı, 2011). Literatürde çeşitli tıbbi ve aromatik bitkilerde tohumlardaki dormansiyi kırmak ve çimlenmeyi teşvik etmek için çok çeşitli uygulamalar yapılarak çimlenme sorununun giderildiğini gösteren çalışmalar mevcuttur (Okay ve Günöz, 2009; Kaya, 2012; Kaya ve ark., 2015; Endes, 2018; Sönmez ve ark., 2019). Bu türden çalışmalarda tohumların gibberellik asit $\left(\mathrm{GA}_{3}\right)$, nitrik asit $\left(\mathrm{HNO}_{3}\right)$, sülfürik asit $\left(\mathrm{H}_{2} \mathrm{SO}_{4}\right)$, potasyum nitrat $\left(\mathrm{KNO}_{3}\right)$ ve kinetin çözeltilerinde veya bunların farklı kombinasyonlarında farklı dozlar ve sürelerde bekletilmesi, ön üşütmeye alınması ve tohum kabuğunun kırılması gibi işlemlerin tohumlarda çimlenme süresini kısalttığı ve çimlenme oranını artırdığı tespit edilmiştir (Ali, 2011; Kırca ve Aygün, 2018).

Türkiye'de özellikle Kuzey Anadolu'da çalılık-fundalık alanlarda yayılış gösteren siyah mürverin üretimi vejetatif veya tohumla generatif olarak yapılmaktadır (Özdemir ve ark., 2019). Ancak, tohumla çoğaltmada dormansi sorunu olduğu için tohumların çimlenme oranı düşmektedir ve çimlenme süresi uzamaktadır (Leif ve ark., 2011). Bu yüzden, tohumda dormansinin kırılarak çimlenme oranının artırılması ve çimlenmenin daha kısa sürede gerçekleşmesi için bazı işlemlerin yapılması gerekli olmaktadır. Buna karşılık, siyah mürverde tohum dormansisinin kırılması ve çimlenmenin teşvik edilmesi konusunda ülkemizde hiçbir çalışma mevcut değildir ve uluslararası literatürdeki çalışma sayısı da yok denecek kadar azdır (Odabaş, 2020). Bu çalışma, ülkemiz doğal florasından toplanan siyah mürver tohumlarında dormansinin kırılması ve çimlenmenin teşvik edilmesi konusunda yürütülen ilk araştırma olma özelliğine sahiptir. Bu gerekçelere uygun olarak bu çalışma siyah mürver tohumlarında dormansinin kırılması ve çimlenmenin teşvik edilmesi üzerine sülfürik, nitrik ve gibberellik asidin etkisini tespit etmek amacıyla yürütülmüştür.

\section{Materyal ve Metot}


Çalışmada bitkisel materyal olarak, ülkemizde Kuzey Anadolu'da doğal yayılış gösteren siyah mürver bitkisinin tohumları kullanılmıştır. Sakarya ili merkez ilçesinde doğal floradan 2018 yılı Ekim ayında toplanan siyah mürver tohumları çimlendirme denemesine alınmadan önce yüzey sterilizasyonuna tabi tutulmuştur (Odabaş, 2020). $\mathrm{Bu}$ amaçla tohumlar \%70'lik alkol içinde 30 saniye tutulduktan sonra, \%25'lik sodyum hipoklorit ( $\mathrm{NaOCl}$ ) çözeltisinde 30 dakika bekletilmiş ve 3 kere distile suyla çalkalanarak sterilizasyon işlemi gerçekleştirilmiştir (Açıkgöz, 2018).

Çimlendirme denemeleri öncesinde, dormansinin kırılması amacıyla, tohumlar derişik sülfürik asit (\%98'lik) ve nitrik asit (\%68'lik) çözeltilerinde 15, 30, 60 ve 90 dakika süreyle bekletilmişlerdir. Asit çözeltilerinden çıkarılan tohumlar 4-5 kez distile su ile yıkanarak asitler uzaklaştırılmıştır. Sülfürik ve nitrik asit çözeltilerinden çıkarılan ve distile su ile yıkanan tohumlar, çimlenmeyi teşvik etmek için 500, 1000 ve 2000 ppm gibberellik asit çözeltisinde 24 saat süreyle bekletilmişlerdir. Sülfürik, nitrik ve $\mathrm{GA}_{3}$ asit ile muamele edilmemiş tohumlar kontrol uygulaması olarak denemede yer almıştır.

Çimlendirme denemeleri tesadüf parsellerinde faktöriyel deneme tertibine göre, sülfürik ve nitrik asit için iki ayrı deneme olarak, 4 tekerrürlü yürütülmüştür. İçlerine çift kat Whatman No.1 filtre kâğıdı yerleştirilmiş petriler deneme öncesinde $115{ }^{\circ} C^{\prime}$ de etüvde sterilize edilmiştir. Her birine 10'ar tohum konulan petri kaplarına $10 \mathrm{ml}$ distile su ilave edilerek, 16 saat ışık/8 saat karanlıkta 22 oC sıcaklıkta iklim odasında bekletilmişlerdir (Odabaş, 2020).

Tohumlarda $2 \mathrm{~mm}$ kökçük çıkışı çimlenme kriteri olarak kabul edilmiş ve denemeye 14. günde son verilmiştir. Çimlenme oranı, kökçük ve sürgün uzunluğu ile kökçük ve sürgün ağırlığına ilişkin ölçüm ve tartımlar 14. gün sonunda her petrideki 10 tohum üzerinde yapılmış ve bütün veriler 10 tohumun ortalaması olarak ifade edilmiştir (Uyanık ve ark.,). Çimlenme oranı (\%), sayım yapıldığı gün çimlenen tohum sayısı / toplam tohum sayısı) x 100 eşitliği uyarınca belirlenmiştir (Şehirali, 2002). Çimlenen tohumlarda kökçük ve sürgün uzunluğu $\mathrm{mm}$, kökçük ve sürgün yaş ağırlığı mg cinsinden ifade edilmiştir.

Denemeden elde edilen veriler, tesadüf parsellerinde faktöriyel deneme tertibine göre varyans analizine tabi tutulmuş ve ortalamalar arasındaki farklılıklar Tukey testi ile belirlenmiştir. Varyans analizinden önce, veriler arasında sıfır değerleri yer aldığı için, tüm verilere $V X+1$ transformasyonu uygulanmıştır (Yurtsever, 1984). Verilerin istatistiki analizi Minitab 17 paket programı kullanılarak yapılmıştır.

\section{Bulgular ve Tartışma}

Siyah mürver tohumlarının çimlenme oranı, kökçük ve sürgün uzunluğu ile kökçük ve sürgün yaş ağırlığı sülfürik ve gibberellik asit uygulamalarına göre çok önemli farklılıklar göstermiştir (Çizelge 1). Tohumların sülfürik asitte 15 dakika bekletilmesi, kontrol uygulamasına göre çimlenmeyi \%38.9 artırmış ve \%67.5 olan ortalama çimlenme oranı \%93.75'e çıkmıştır. Tohumların 30 dakika sülfürik asitte bekletmesi çimlenmeyi önemli derecede azaltmış, 60 ve 90 dakikalık sürelerde çimlenme neredeyse sıfıra kadar düşmüştür.

Sülfürik asitle muamele edilmeyen mürver tohumlarında gibberellik asit çimlenme oranı üzerine hiçbir etki göstermemiş ve artan gibberellik asit dozlarında çimlenme oranı değişmeden \%67.50 olarak kalmıştır. Benzer durum, incelenen diğer özellikler için de geçerlidir. Buna karşılık, sülfürik asitle ön muameleye tabi tutulan siyah mürver tohumlarında gibberellik asit uygulaması çimlenme oranı ve fide gelişimini çok önemli ölçüde etkilemiştir. Nitekim 15 dakika sülfürik asitte bekletildikten sonra 500 ppm GA $\mathrm{A}_{3}$ çözeltisinde 24 saat tutulan siyah mürver tohumlarında çimlenme oranı sülfürik ve gibberellik asit uygulanmayan tohumlara göre \%48.10 oranında artarak \%100'e ulaşmıştır.

Farklı sürelerde nitrik asit çözeltisinde bekletildikten sonra farklı dozlardaki gibberellik asit çözeltisinde 24 saat tutulan siyah mürver tohumlarında çimlenme oranı, kökçük ve sürgün uzunluğu ile kökçük ve sürgün yaş ağırlığı Çizelge 2'de verilmiştir.

Nitrik asit uygulaması siyah mürver tohumlarının çimlenmesi ve fide gelişimini olumsuz yönde etkilemiş ve bütün nitrik asit uygulamalarında kontrole göre daha düşük değerler elde edilmiştir. Nitekim nitrik asitte bekletilmemiş siyah mürver tohumlarında \%67.50 olan çimlenme oranı tohumların 15 dakika nitrik asitte bekletilmesiyle $\% 78.8$ oranında azalmış ve \%14.38'e düşmüştür. Ayrıca nitrik asitte bekletme süresi uzadıkça, tohumların çimlenme oranı ve fide gelişimi de çok önemli derecede azalmış ve hatta bazı 60 ve 90 dakikalık sürelerde çimlenme olmamıştır.

Diğer taraftan, nitrik asitle ön muameleye tabi tutulmuş mürver tohumlarının gibberellik asit çözeltisinde bekletilmesi olumlu etki yapmak yerine çimlenme üzerine olumsuz etkide bulunmuş ve hatta nitrik asidin engelleyici etkisini daha da artırmıştır. Nitekim gibberellik asit uygulanmayan tohumlarda \%29.50 olan ortalama çimlenme oranı, artan $\mathrm{GA}_{3}$ dozlarında (500, 1000 ve 2000 ppm) sırasıyla \%14.50, \%16.00 ve \%14.50'ye kadar düşmüştür (Çizelge 2). 
Çizelge 1. Farklı sürelerde sülfürik asitte tutulduktan sonra farklı dozlardaki gibberellik asitte 24 saat bekletilen siyah mürver tohumlarının çimlenme oran, kökçük ve sürgün uzunluğu ile kökçük ve sürgün yaş ağırlığı.

\begin{tabular}{|c|c|c|c|c|c|c|}
\hline \multirow{3}{*}{$\begin{array}{c}\mathrm{GA}_{3} \text { Dozu } \\
(\mathrm{ppm})\end{array}$} & \multicolumn{6}{|c|}{ Sülfürik Asitte Bekletme Süresi (dakika) } \\
\hline & 0 & 15 & 30 & 60 & 90 & Ortalama \\
\hline & \multicolumn{6}{|c|}{ Çimlenme Oran (\%) } \\
\hline 0 & $67.50 \mathrm{ab}^{*}$ & $75.00 \mathrm{ab}$ & $40.00 \mathrm{bc}$ & 7.50 def & 0.00 & 38.00 \\
\hline 500 & $67.50 \mathrm{ab}$ & $100.00 \mathrm{a}$ & $25.00 \mathrm{~cd}$ & 0.00 & 0.00 & 38.50 \\
\hline 1000 & $67.50 \mathrm{ab}$ & $100.00 \mathrm{a}$ & $40.00 \mathrm{bc}$ & 0.00 & 5.00 ef & 42.50 \\
\hline 2000 & $67.50 \mathrm{ab}$ & $100.00 \mathrm{a}$ & 20.00 cde & 7.50 def & 5.00 ef & 40.00 \\
\hline Ortalama & $67.50 \mathrm{~B}$ & $93.75 \mathrm{~A}$ & $31.25 \mathrm{C}$ & $3.75 \mathrm{D}$ & $2.50 \mathrm{D}$ & \\
\hline \multicolumn{7}{|c|}{ Kökçük Uzunluğu (mm) } \\
\hline 0 & $2.87^{*}$ & 2.80 & 0.35 & 0.32 & 0.00 & 1.27 \\
\hline 500 & 2.87 & 3.52 & 0.32 & 0.00 & 0.00 & 1.34 \\
\hline 1000 & 2.87 & 2.20 & 0.00 & 0.00 & 0.17 & 1.05 \\
\hline 2000 & 2.87 & 2.01 & 0.02 & 0.02 & 0.17 & 1.02 \\
\hline Ortalama & $2.87 \mathrm{~A}$ & $2.63 \mathrm{~A}$ & $0.17 \mathrm{~B}$ & $0.09 \mathrm{~B}$ & $0.09 \mathrm{~B}$ & \\
\hline \multicolumn{7}{|c|}{ Sürgün Uzunluğu (mm) } \\
\hline 0 & 1.07 cde* $^{*}$ & $3.06 \mathrm{a}$ & $1.50 \mathrm{bcd}$ & 0.28 ef & 0.00 & $1.18 \mathrm{~A}$ \\
\hline 500 & 1.07 cde & $2.60 \mathrm{ab}$ & 0.60 cdef & 0.00 & 0.00 & $0.85 \mathrm{AB}$ \\
\hline 1000 & $1.07 \mathrm{cde}$ & $1.55 \mathrm{bc}$ & $1.45 \mathrm{bcd}$ & 0.00 & $0.05 f$ & $0.82 \mathrm{AB}$ \\
\hline 2000 & $1.07 \mathrm{cde}$ & $1.38 \mathrm{bcd}$ & 0.45 def & $0.03 \mathrm{f}$ & $0.10 \mathrm{f}$ & $0.61 \mathrm{~B}$ \\
\hline Ortalama & $1.07 \mathrm{~B}$ & $2.15 \mathrm{~A}$ & $1.01 \mathrm{~B}$ & 0.08 & $0.04 \mathrm{C}$ & \\
\hline \multicolumn{7}{|c|}{ Kökçük Yaş Ağırlığı (mg) } \\
\hline 0 & 0.218 & 0.105 & 0.025 & 0.006 & 0.000 & 0.071 \\
\hline 500 & 0.218 & 0.110 & 0.010 & 0.000 & 0.000 & 0.068 \\
\hline 1000 & 0.218 & 0.125 & 0.000 & 0.000 & 0.032 & 0.075 \\
\hline 2000 & 0.218 & 0.123 & 0.002 & 0.023 & 0.006 & 0.074 \\
\hline Ortalama & $0.218 A^{*}$ & $0.116 \mathrm{~B}$ & $0.009 \mathrm{C}$ & $0.007 \mathrm{C}$ & $0.009 \mathrm{C}$ & \\
\hline \multicolumn{7}{|c|}{ Sürgün Yaş Ağırlığı (mg) } \\
\hline 0 & 0.233 & 0.165 & 0.145 & 0.042 & 0.000 & 0.117 \\
\hline 500 & 0.233 & 0.280 & 0.133 & 0.000 & 0.000 & 0.129 \\
\hline 1000 & 0.233 & 0.300 & 0.050 & 0.000 & 0.016 & 0.120 \\
\hline 2000 & 0.233 & 0.207 & 0.021 & 0.005 & 0.024 & 0.098 \\
\hline Ortalama & $0.233 A^{*}$ & $0.238 \mathrm{~A}$ & $0.087 \mathrm{~B}$ & $0.012 \mathrm{C}$ & $0.010 \mathrm{C}$ & \\
\hline
\end{tabular}

*: Aynı harfe gösterilen ortalamalar arasında istatistiki olarak önemli $(P<0.05)$ fark yoktur

Literatürde ülkemizde doğal olarak yayılış gösteren siyah mürver tohumlarında dormansinin kırılması ve çimlenmenin teşvik edilmesi konusunda hiçbir çalışma mevcut olmadığı için bu araştırmadan elde edilen bulguların bilimsel literatürle karşılaştırılmalı olarak tartışılması mümkün olamamıştır. Uluslararası literatürde de mürver tohumlarında dormansi ve çimlenme konusunda yapılan çalışmalar oldukça sınırlıdır. Leif ve ark. (2011) tarafından yapılan bir çalışmada, dormansi sorunu tespit edilen siyah mürver tohumlarında en yüksek çimlenme oranının tohumların 10 dakika sülfürik asitte (\%90'lık) bekletildikten sonra 60 gün soğukta katlama uygulamasından alındığı bildirilmiştir.

$\mathrm{Bu}$ araştırmadan elde edilen bulgular siyah mürver tohumlarını konsantre sülfürik asitte belirli süre bekletmenin dormansinin kırılmasında etkili olduğunu göstermiştir. Sülfürik asit çözeltisinde 15 dakika bekletilen siyah mürver tohumlarında çimlenme oranı $\mathrm{H}_{2} \mathrm{SO}_{4}$ ve $\mathrm{GA}_{3}$ uygulanmayan kontrol tohumlarına göre \%11.1 oranında artış göstermiştir. Buna karşılık mürver tohumlarının 15 dakikadan daha uzun süreyle sülfürik asitle muamele edilmesi çimlenme oranı ve fide gelişimini çok önemli ölçüde azaltmıştır. Ayrıca sülfürik asitle ön muameleye tabi tutulmayan siyah mürver tohumlarında gibberellik asit hiçbir özellik üzerine olumlu veya olumsuz herhangi bir etki göstermemiştir. Bu bulgular, siyah mürver tohumlarındaki dormansinin muhtemelen tohum kabuğundan kaynaklanan fiziksel dormansi olduğunu destekler mahiyettedir. Bilindiği gibi, fiziksel dormanside sert ve geçirimsiz tohum kabuğu su ve gazların geçirgenliğine engel olmakta ve bunun sonucunda da çimlenme tamamen ya da kısmen engellenmektedir (Baskin ve ark., 2000). Isste böyle durumlarda, sert tohum kabuğunu 
yumuşatarak suyun geçirgenliğine imkân veren asit uygulaması dormansinin kırılmasında oldukça etkili olabilmektedir. Nitekim çalışmamızdan elde edilen veriler de siyah mürver tohumlarının 15 dakika sülfürik asitte bekletilmesiyle tohum kabuğunun yumuşayarak suya karşı geçirgenleştiğini ve bunun sonucunda su alan tohumlarda çimlenin arttığını doğrulamaktadır.

Diğer taraftan, 15 dakika sülfürik asitte bekletildikten sonra 24 saat 500 ppmlik gibberellik asit çözeltisinde tutulan siyah mürver tohumlarında çimlenme ve fide gelişiminde oldukça önemli artışlar görülmüştür. Sülfürik asitte 15 dakika tutulduktan sonra 500 ppmlik gibberellik asit çözeltisinde 24 saat bekletilen siyah mürver tohumlarında, kontrol tohumlarına oranla, çimlenme oranı ile kökçük ve sürgün uzunluğu sırasıyla \%48.1, \%22.6 ve \%143.0 oranlarında artmıştır. Bu bulgular, çalışmada kullanılan siyah mürver tohumlarında sadece fiziksel değil, aynı zamanda fizyolojik dormansinin de etkili olduğunu (birleşik dormansi) göstermektedir (Baskin ve Baskin, 2004; Kucera ve ark., 2005).

Çizelge 2. Farklı sürelerde nitrik asitte tutulduktan sonra farklı dozlardaki gibberellik asitte 24 saat bekletilen siyah mürver tohumlarının çimlenme oran, kökçük ve sürgün uzunluğu ile kökçük ve sürgün yaş ağırlığı.

\begin{tabular}{|c|c|c|c|c|c|c|}
\hline \multirow{3}{*}{$\begin{array}{c}\mathrm{GA}_{3} \text { Dozu } \\
\text { (ppm) }\end{array}$} & \multicolumn{6}{|c|}{ Nitrik Asitte Bekletme Süresi (dakika) } \\
\hline & 0 & 15 & 30 & 60 & 90 & Ortalama \\
\hline & \multicolumn{6}{|c|}{ Çimlenme Oran (\%) } \\
\hline 0 & $67.50 a^{*}$ & $40.00 \mathrm{a}$ & $32.50 \mathrm{a}$ & $5.00 \mathrm{~b}$ & $2.50 \mathrm{~b}$ & $29.50 \mathrm{~A}$ \\
\hline 500 & $67.50 \mathrm{a}$ & $5.00 \mathrm{~b}$ & 0.00 & 0.00 & 0.00 & $14.50 \mathrm{~B}$ \\
\hline 1000 & $67.50 \mathrm{a}$ & $10.00 \mathrm{~b}$ & $2.50 \mathrm{~b}$ & 0.00 & 0.00 & $16.00 \mathrm{~B}$ \\
\hline 2000 & $67.50 \mathrm{a}$ & $2.50 \mathrm{~b}$ & 0.00 & $2.50 \mathrm{~b}$ & 0.00 & $14.50 \mathrm{~B}$ \\
\hline Ortalama & $67.50 \mathrm{~A}$ & $14.38 \mathrm{~B}$ & $8.75 \mathrm{BC}$ & $1.88 \mathrm{CD}$ & $0.63 \mathrm{D}$ & \\
\hline \multicolumn{7}{|c|}{ Kökçük Uzunluğu (mm) } \\
\hline 0 & $2.87 a^{*}$ & $1.73 \mathrm{~b}$ & $1.27 \mathrm{~b}$ & $0.21 \mathrm{c}$ & $0.15 \mathrm{c}$ & $1.25 \mathrm{~A}$ \\
\hline 500 & $2.87 a$ & $0.22 \mathrm{c}$ & 0.00 & 0.00 & 0.00 & $0.62 \mathrm{~B}$ \\
\hline 1000 & $2.87 a$ & $0.29 \mathrm{c}$ & $0.12 \mathrm{~cd}$ & 0.00 & 0.00 & $0.66 \mathrm{~B}$ \\
\hline 2000 & $2.87 a$ & $0.07 \mathrm{~d}$ & 0.00 & $0.05 d$ & 0.00 & $0.60 \mathrm{~B}$ \\
\hline Ortalama & $2.87 \mathrm{~A}$ & $0.58 \mathrm{~B}$ & $0.35 \mathrm{BC}$ & $0.07 \mathrm{C}$ & $0.04 \mathrm{C}$ & \\
\hline \multicolumn{7}{|c|}{ Sürgün Uzunluğu (mm) } \\
\hline 0 & $1.07 a^{*}$ & $1.92 \mathrm{a}$ & $1.62 \mathrm{a}$ & $0.22 \mathrm{~b}$ & $0.12 \mathrm{~b}$ & $0.99 \mathrm{~A}$ \\
\hline 500 & $1.07 \mathrm{a}$ & $0.07 \mathrm{~b}$ & 0.00 & 0.00 & 0.00 & $0.23 \mathrm{~B}$ \\
\hline 1000 & $1.07 \mathrm{a}$ & $0.17 \mathrm{~b}$ & $0.05 \mathrm{~b}$ & 0.00 & 0.00 & $0.26 \mathrm{~B}$ \\
\hline 2000 & $1.07 \mathrm{a}$ & $0.03 \mathrm{~b}$ & 0.00 & $0.02 \mathrm{~b}$ & 0.00 & $0.22 \mathrm{~B}$ \\
\hline Ortalama & $1.07 \mathrm{~A}$ & $0.55 \mathrm{~B}$ & $0.42 \mathrm{~B}$ & $0.06 \mathrm{C}$ & $0.03 \mathrm{C}$ & \\
\hline \multicolumn{7}{|c|}{ Kökçük Yaş Ağırlığı (mg) } \\
\hline 0 & $0.218 a^{*}$ & $0.195 a b$ & $0.105 \mathrm{bc}$ & $0.018 \mathrm{~cd}$ & $0.003 d$ & $0.108 \mathrm{~A}$ \\
\hline 500 & $0.218 \mathrm{a}$ & $0.020 \mathrm{~cd}$ & 0.000 & 0.000 & 0.000 & 0.048 B \\
\hline 1000 & $0.218 \mathrm{a}$ & $0.018 \mathrm{~cd}$ & $0.015 \mathrm{~cd}$ & 0.000 & 0.000 & $0.050 \mathrm{~B}$ \\
\hline 2000 & $0.218 a$ & $0.005 \mathrm{~d}$ & 0.000 & $0.003 \mathrm{~d}$ & 0.000 & $0.045 \mathrm{~B}$ \\
\hline Ortalama & $0.218 \mathrm{~A}$ & 0.059 B & $0.030 \mathrm{BC}$ & $0.005 \mathrm{C}$ & $0.001 \mathrm{C}$ & \\
\hline \multicolumn{7}{|c|}{ Sürgün Yaş Ağırlığı (mg) } \\
\hline 0 & 0.233 & 0.080 & 0.064 & 0.010 & 0.005 & $0.078 \mathrm{~A}$ \\
\hline 500 & 0.233 & 0.009 & 0.000 & 0.000 & 0.000 & $0.048 \mathrm{~B}$ \\
\hline 1000 & 0.233 & 0.012 & 0.012 & 0.000 & 0.000 & $0.051 \mathrm{~B}$ \\
\hline 2000 & 0.233 & 0.006 & 0.000 & 0.008 & 0.000 & $0.049 \mathrm{~B}$ \\
\hline Ortalama & $0.233 A^{*}$ & $0.027 \mathrm{~B}$ & $0.019 \mathrm{~B}$ & $0.004 \mathrm{~B}$ & $0.001 \mathrm{~B}$ & \\
\hline
\end{tabular}

*: Aynı harfe gösterilen ortalamalar arasında istatistiki olarak önemli $(P<0.05)$ fark yoktur

Siyah mürver tohumlarının 30 dakika sülfürik asitte bekletilmesi çimlenmeyi kontrol tohumlarına göre oldukça önemli derecede azaltmış, 60 ve 90 dakikalık bekletme sürelerinde 
ise çimlenme oranları sıfıra yaklaşmıştır (sırasıyla \%3.75 ve \%2.50). Siyah mürver tohumlarının 15 dakikadan daha uzun sürede sülfürik asitte bekletilmesiyle çimlenme oranı ve fide gelişiminin çok önemli derecede azalıyor olması, muhtemelen sülfürik asidin tohum kabuğunu çok fazla aşındırdığını ve artık tohumdaki embriyoya zarar vermeye başladığını ortaya koymaktadır. Buna göre, siyah mürver tohumunda dormansinin kırılması ve optimum çimlenme oranı (\%100) için tohumların 15 dakikadan daha uzun süre sülfürik asit içinde bekletilmesi uygun değildir. Araştırmamızdan elde edilen bulgulara benzer olarak, guava tohumlarında çimlenme oranının sülfürik asitte bekletme süresi ve uygulama dozlarındaki artışla giderek azaldığı ve bunun $\mathrm{H}_{2} \mathrm{SO}_{4}$ 'in tohum embriyosuna ulaşarak tohuma zarar vermesinden kaynaklandığı bildirilmiştir (Akın ve ark., 2019; Adak ve ark., 2019).

Nitrik asitle yürütülen denemede, en kısa bekletme süresinde (15 dakika) bile siyah mürver tohumlarının çimlenme oranı ve fide gelişmesinde çok yüksek oranlarda kayıplar görülmüştür. Buna göre, siyah mürver tohumlarında dormansinin kırılması için ön uygulama olarak konsantre nitrik asidin kullanılmasının uygun olmayacağı sonucuna varılabilir. Konsantre asitlerde belirli süre bekletilen bitki tohumlarında çimlenmenin asitle muamele edilmeyen tohumlara göre daha düşük olması ya sürenin yetersiz (tohum kabuğu suya geçirgen değil) ya da fazla (embriyo zarar görmüş) olmasıyla izah edilebilir (Muhammad, 2018; Maldonado-Arciniegas ve ark., 2018). Nitrik asidin kontrol uygulamasına oranla çimlenme oranını azalttığını gösteren benzer sonuçlar Corchorus tridens bitkisinde Emongor ve ark. (2004) tarafından da rapor edilmiştir. Nitekim 10, 20 ve 30 dakika konsantre nitrik asitte tutulan tohumların çimlenme yüzdesi distile su içinde bekletilen tohumlara göre çok daha düşük olmuştur. Buna karşılık Ajiboye (2010), Tamarindus indica bitkisinde dormansinin kırılmasında nitrik asidin olumlu etkisinin olduğunu rapor etmektedir. Sülfürik ve nitrik asitle iki ayrı denemeli olarak yürütülen çalışmada gibberellik asit genellikle incelenen özellikler üzerine olumsuz yönde etkide bulunmuştur.

Bununla birlikte, 15 dakika sülfürik asitte bekletildikten sonra 500 ppm GA $\mathrm{A}_{3}$ çözeltisinde 24 saat tutulan siyah mürver tohumlarında çimlenme oranı \%48.1 oranında artışla \%100 değerine ulaşmıştır. Gibberellik asit 15 dakikadan daha uzun süre derişik sülfürik asitte bekletilen siyah mürver tohumlarının çimlenmesi üzerine teşvik edici etkide bulunmak yerine, tam tersine olumsuz etki yapmıştır. Nitrik asitle yürütülen denemede ise çimlenme ve fide gelişimi üzerine gibberellik asidin hiçbir olumlu etkisiz söz konusu değildir. Tersine bütün özelliklerde gibberellik asit dozlarındaki artışa paralel olarak çok önemli azalmalar ortaya çıkmıştır. Gibberellik asit esas olarak embriyonun büyüme potansiyelini artırarak çimlenmeyi teşvik etmekte ve ayrıca tohum kabuğunun direncinin azalmasında etkili olmaktadır (Kucera ve ark. 2005). Literatürde skarifikasyon uygulamalarıyla birlikte kullanıldığında gibberellik asidin genellikle çimlenmeyi artırdığı rapor edilmektedir (Bayrak, 2016; Gökçöl ve Duman, 2018). Bizim çalışmamızda kullanılan sülfürik asit ve nitrik asidin konsantre asitler olması ve bekletme süresinin siyah mürver için uzun olması sebebiyle tohum embriyosu bu asitlerce çok fazla zarara uğratılmış olabilir. Bu şekildeki tohumlarda ise gibberellik asidin embriyonun büyüme potansiyelini ve çimlenmeyi artırması beklenmemelidir.

\section{Sonuç ve Öneriler}

$\mathrm{Bu}$ araştırmadan elde edilen bulgular siyah mürver tohumlarının 15 dakika ve daha üzerindeki sürelerde nitrik asitte bekletilmesinin çimlenmeyi ve fide gelişimini çok önemli ölçüde engellediğini ortaya koymuştur. Diğer taraftan, siyah mürver tohumlarının 30 dakikadan daha fazla sürelerde derişik sülfürik asitte bekletilmesiyle çimlenme ve fide gelişimi önemli ölçüde gerilemiştir. Buna karşılık siyah mürver tohumlarının önce 15 dakika sülfürik asitte bekletilmesi ve sonra 500 ppmlik gibberellik asit çözeltisinde 24 saat tutulmasıyla çimlenme oranı \%100 olmuş ve fide gelişimi artmıştır. Bu bulgular siyah mürver tohumlarında fiziksel ve fizyolojik dormansinin birlikte (birleşik dormansi) etkili olduğunu ortaya koymaktadır. Sonuç olarak dormansinin kırılması, optimum çimlenme ve fide gelişiminin sağlanması için siyah mürver tohumlarının önce 15 dakika derişik sülfürik asitte ve sonra 24 saat süreyle 500 ppmlik gibberellik asitte bekletilmesi önerilebilir.

¥: Bu çalışma 1. yazarın yüksek lisans tezinden türetilmiştir.

Çıkar Çatışması Beyanı: Makale yazarları aralarında herhangi bir çıkar çatışması olmadığını beyan ederler.

Araştırmacıların Katkı Oranı Beyan Özeti: Yazarlar makaleye eşit oranda katkı sağlamış olduklarını beyan ederler.

\section{Kaynaklar}

Açıkgöz, M.A. 2018. Ferula lycia Boiss ve Achillea gypsicola türlerinde kallus kültürü ile sekonder metabolit üretim potansiyelinin 
belirlenmesi. Doktora Tezi, Ordu Üniversitesi Fen Bilimleri Enstitüsü Tarla Bitkileri Anabilim Dalı, Ordu.

Adak, N., Balkıç, R., Tozlu, İ., Altınkaya, L., Soydal, A. ve Gübbük, H. 2019. Guava (Psidium guajava L.) tohumlarının çimlenmesi üzerine araştırmalar. Bahçe, 48 (1): 1-7.

Ajiboye, A.A. 2010. Dormancy and seed germination in Tamarindus indica (L). The Pacific Journal of Science and Technology, 11 (2): 463-470.

Akın, M., Ekin, Z., Ozmen, S. ve Kaya, M. 2019. Seed dormancy in Rheum ribes. collected from natural populations in Turkey. International Journal of Scientific and Technological Research, doi: 10.7176/JSTR/5, 2-22.

Ali, A. 2011. Bazı tohum ön uygulamalarının yağlık ve çerezlik ayçiçeği (Helianthus annuus L.) tohumlarının stres sıcaklıklarında çimlenme ve çıkış performansı üzerine etkileri, Yüksek Lisans Tezi, Ankara Üniversitesi Fen Bilimleri Enstitüsü Tarla Bitkileri Anabilim Dalı, Ankara.

Atkinson, M.D. ve Atkinson, E.A. 2002. Sambucus nigra L. Journal of Ecology, 90: 895-923.

Baskin, J.M., Baskin, C.C. ve Li, X. (2000) Taxonomy, ecology, and evolution of physical dormancy in seeds. Plant Species Biology 15: 139-152.

Baskin J.M. ve Baskin C.C. 2004. A classification system for seed dormancy. Seed Science Research, 14: 1-16.

Baydar, H. 2019. Tıbbi ve Aromatik Bitkiler Bilimi ve Teknolojisi. 7. Basım, Nobel Akademik Yayıncılık, Ankara, $411 \mathrm{~s}$.

Bayrak, M. 2016. Hypericum adenotrıchum Spach. (Hypericaceae; Clusiaceae) türünün tohum çimlenmesi üzerinde araştırmalar. Yüksek Lisans Tezi, Uludağ Üniversitesi, Fen Bilimleri Enstitüsü, Biyoloji Anabilim Dalı, Bursa.

Boyraz, M., Korkmaz, H. ve Durmaz, A. 2019. Tohumda dormansi ve çimlenme. Black Sea Journal of Engineering and Science, 2 (3): 92-105.

Emongor, V.E., Mathowa, T. ve Kabelo, S. 2004. The effect of hot water, sulfuric acid, nitric acid, gibberellic acid and etheplon on germination of Corchorus (Corchorus tridens) seed. Journal of Agronomy, 3 (3): 196-200.

Endes, Z. 2018. Bazı tohum ön uygulamalarının iki farklı çörek otu türüne ait (Nigella sativa L. ve Nigella damascena L.) tohumların çimlenme ve çıkış performansı üzerine etkileri1eri. Selçuk Tarım ve Gıda Bilimleri Dergisi, 32 (1): 29-37.

Faydaoğlu, E. ve Sürücüoğlu, M.S. 2011. Geçmişten günümüze tıbbi ve aromatik bitkilerin kullanılması ve ekonomik önemi. Kastamonu Üniversitesi Orman Fakültesi Dergisi, 11 (1): 52-67.

Gökçöl, A. ve Duman, ì. 2018. Kapari tohumlarının çimlenmesinin iyileştirilmesinde farklı tohum uygulamalarının etkisinin belirlenmesi. Ege Üniversitesi Ziraat Fakültesi Dergisi, 54 (4): 433-440.

Göktaş, Ö. ve Gıdık, B. 2019. Tıbbi ve aromatik bitkilerin kullanım alanları. Bayburt Üniversitesi Fen Bilimleri Dergisi, 2 (1): 145-151.

Hayta, E. ve Arabacı, O. 2011. Kekik olarak adlandırılan bazı bitki cinslerinin tohumlarında farklı çimlendirme yöntemlerinin belirlenmesi. Adnan Menderes Üniversitesi Ziraat Fakültesi Dergisi, (8) 1: 91-101.

Karakurt, H., Aslantaş, R. ve Eşitken, A. 2010. Tohum çimlenmesi ve bitki büyümesi üzerinde etkili olan çevresel faktörler ve bazı ön uygulamalar. Uludağ Üniversitesi Ziraat Fakültesi Dergisi, 24 (2): 115-128.

Kaya, M.D., Kulan, E.G., Gümüşçü, G. ve Gümüşçü, A. 2015. Factors affecting germination performance of four endemic sideritis species in Turkey. Journal of Agricultural Sciences, 21: 406-413.

Kaya, T. 2012. Ön üşütme süresi ve kinetin uygulamalarının kebere (Capparis spinosa var. spinosa ve Capparis ovata var. canescens) tohumlarının çimlenmesi üzerine etkisi. Yüksek Lisans Tezi, Ankara Üniversitesi Fen Bilimleri Enstitüsü, Tarla Bitkileri Anabilim Dalı, Ankara.

Kırca, L. ve Aygün, A. 2018. Ahlat (Pyrus elaeagrifolia Pall.) tohumlarının çimlenmesi üzerine potasyum nitrat uygulamalarının etkisi. Bahçe, 47 (2): 5862.

Kucera, B., Cohn, M.A. ve Leubner-Metzger, G. 2005. Plant hormone interactions during seed dormancy release and germination. Seed Science Research, 15: 281-307.

Leif, J.W., Durling J.C. ve Burgdorf, D.W. 2011. Comparison of seed germination techniques for common elderberry (Sambucus nigra L. ssp. canadensis). Nativeplants, 12 (2): 132-135

Maldonado-Arciniegas, F., Ruales, C., Caviedes, M., Ramírez, DX. ve León-Reyes, A. 2018. An evaluation of physical and mechanical scarification methods on seed 
germination of Vachellia macracantha (Humb. \& Bonpl. ex Willd.) Seigler \& Ebinger. Acta Agronómica, 67 (1): 120125.

Miraj, S. 2016. Chemical composition and pharmacological effects of Sambucus nigra. Der Pharma Chemica, 8 (13): 231234.

Muhammad, M.T. 2018. The effect of priming and artificial dormancy breaking techniques on germination and seedling establishment of date palm. Research \& Reviews: Research Journal of Biology, 6 (3): 13-17.

Odabaş, S. 2020. Kimyasal uygulamalarının siyah mürver (Sambucus nigra L.) tohumlarında dormansinin kırılması ve çimlenme üzerine etkisi. Yüksek Lisans Tezi, Ordu Üniversitesi, Fen Bilimleri Enstitüsü, Tarla Bitkileri Anabilim Dalı, Ordu.

Okay, Y. ve Günöz, A. 2009. Gölbaşı'na endemik Centaurea tchihatcheffii Fisch et Mey. tohumlarının çimlenmesi üzerine bazı uygulamaların etkisi. Tarım Bilimleri Dergisi, 15 (2): 119-126.

Olgun, Ç., Özkan, O.E. ve Vurdu, H. 2012. Kastamonu'da yetişen mürver türlerinin botanik ve kullanım özellikleri. Kastamonu'nun Doğal Zenginlikleri Sempozyumu, 16-17 Ekim, Kastamonu, s. 46-49.

Özdemir, M., Arslanoğlu, Ş.F. ve Sert, Ö.S. 2019. Anadolu coğrafyasında yayılış gösteren Sambucus nigra ve Sambucus ebulus'un tıbbi bitki olarak önemi. Agromedya, Haziran-Temmuz: 58-62.

Sönmez, Ç., Gökçöl , A., Soysal Şimşek, A.Ö., Bayram, E. ve Çelen, A.E. 2019. Research on germination and emergence performance enhancing treatments on sage (Salvia spp.) species. Turkish Journal of Agriculture - Food Science and Technology, 7 (3): 504-510.

Şehirali, S. 2002. Tohumluk ve Teknolojisi. Trakya Üniv. Tekirdağ Ziraat Fak. Yayın No: 4075/2. İstanbul. 447s.

Uyanık, M., Kara, Ş.M. ve Korkmaz, K. 2014. Bazı kışlık kolza (Brassica napus L.) çeşitlerinin çimlenme döneminde tuz stresine tepkilerinin belirlenmesi. Tarım Bilimleri Dergisi 4 (20): 368-375.

Yurtsever, N. 1984. Deneysel Istatistik Metotları. Tarım ve Orman Bakanlığı Köy. Hizmetleri Genel Müd. Yayınları 121 (56), 574 s. Ankara.

Zakay-Rones, Z., Thom, E., Wollan, T. ve Wadstein, J. 2004. Randomized study of the efficacy and safety of oral elderberry extract in the treatment of influenza $A$ and $B$ virus infections. Journal of International Medical Research, 32 (2): 132-140. 